\title{
Distancias a vencer y mitos a romper: El establecimiento de las relaciones diplomáticas mexicano-polacas ${ }^{1}$
}

Distances to beat and myths to break: The establishment of Mexican-Polish diplomatic relations

Edyta, Kwiatkowska-Faryś ${ }^{2}$

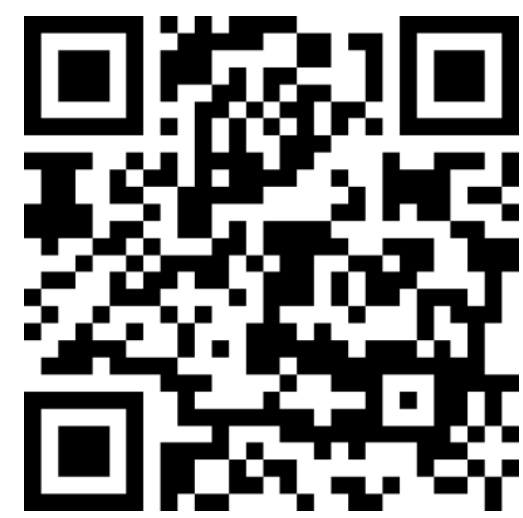

.....

Fecha de recibido: 08-01-2021

Fecha de aceptado: 27-06-2021

\section{(cc) BY-NC-ND}

Esta obra está bajo una licencia de Creative Commons Reconocimiento-NoComercialSinObraDerivada 4.0 Internacional

\begin{abstract}
RESUMEN
El presente artículo es producto de una revisión documental cuyo objetivo consistió en sistematizar la información y describir las condiciones sociopolíticas del entablamiento de las relaciones diplomáticas bilaterales entre México y Polonia. Se aplicó el método de selección y análisis de fuentes, el tipo de investigación es cualitativa. Se encontró que la relación política de Polonia y México partió del desconocimiento mutuo y una serie de tópicos, siendo una de las primeras tareas de los gobiernos la de rectificar o confirmar las respectivas imágenes de los países. Se concluye que las dos décadas iniciales de contactos oficiales testimonian la evolución de los conceptos sociopolíticos y la consolidación de estas imágenes estereotipadas.
\end{abstract}

Palabras claves: Diplomáticos, estereotipos, relaciones mexicano-polacas.

\begin{abstract}
This article is the result of a documentary review whose objective consisted in gathering information and describing the socio-political conditions of the establishment of bilateral diplomatic relations between Mexico and Poland. The method of selection and analysis of sources was applied, the type of research is qualitative. It was found that the political relationship between Poland and Mexico started from mutual ignorance and a series of topics, being one of the first tasks of the governments to rectify or confirm the respective images of the countries. It is concluded that the initial two decades of official contacts witness the evolution of socio-political concepts and the consolidation of these stereotyped images.
\end{abstract}

Keywords: Diplomats, Mexican-Polish relations, stereotypes.

Cómo referenciar este artículo:

Kwiatkowska-Faryś, E. (2022). Distancias a vencer y mitos a romper: el establecimiento de las relaciones diplomáticas mexicano-polacas. Revista Política, Globalidad y Ciudadanía, 8(15), 152-170. https://doi.org/10.29105/pgc8.15-8

\footnotetext{
${ }^{1}$ Este artículo es producto del proyecto de la Embajada de México en Polonia, iniciado y finalizado en 2021.

${ }^{2}$ Uniwersytet im. Adama Mickiewicza w Poznaniu, Polonia. Doctora en Humanidades por la Universidad de Poznan, profesora encargada en la Universidad Adam Mickiewicz de Poznan. Email: edyta.kwiatkowska@amu.edu.pl. ORCID ID: 0000-0003-4765-6202.
} 


\section{1.- INTRODUCCIÓN}

El México contemporáneo es uno de los socios prioritarios de Polonia en América Latina. El animado desarrollo de contactos comerciales y empresariales, las costumbres y expresiones culturales comunes, así como las tradiciones democráticas de ambos países se consideran las principales determinantes del fortalecimiento de las relaciones bilaterales. El marco comunitario europeo es el factor adicional que refuerza la cooperación entre Polonia y México.

Las relaciones económicas entre Polonia y México, que se entablaron en el siglo XIX y se formalizaron gradualmente a finales de los años veinte del siglo pasado, son más antiguas que las relaciones diplomáticas y consulares. Se han caracterizado por una dinámica débil y sólo han aumentado notablemente en la década de 1990. Teniendo en cuenta el volumen de comercio en la última década, México se mantiene como tercer socio comercial de Polonia en América Latina. Por su situación geográfica, tamaño del mercado y potencial económico, sigue siendo uno de los socios económicos polacos más importantes del hemisferio occidental.

No obstante, las centenarias relaciones políticas entre Polonia y México, en los años 20 del siglo pasado nacían en un entorno - real e imaginario - bastante desfavorable, marcado por el mutuo desconocimiento y desprecio. Este estudio recoge los conocimientos en la materia de los inicios de las relaciones entre Polonia y México: bilaterales, mutuas y voluntarias entre gobiernos.

Partimos de la premisa de que igual a la cultura popular (cine, prensa, reportajes) del principio del siglo XX, el discurso diplomático que documenta la relación política bilateral, emprendida a partir del año 1928, contribuye a la percepción de Polonia en México y de México en Polonia, basada en tópicos y simplificaciones. La intención es poner de manifiesto la tarea que se propusieron ambos países de vencer la desconfianza institucional y política entre los dos Estados que se acababan de redefinir. En el artículo nos centraremos entonces en las primeras décadas de las relaciones bilaterales, partiendo del año 1918 y poniendo como cesura natural el momento del histórico cambio geográfico e ideológico que sufrió Polonia al finalizarse la Segunda Guerra Mundial (1945).

El intento del acercamiento oficial de Polonia y México tuvo lugar tras la reaparición de Polonia en el mapa político del mundo, estableciéndose finalmente la relación diplomática de la II República de Polonia y el México posrevolucionario en la segunda década del siglo XX. 
En 1921 México recibió solicitud de reconocimiento de Polonia, y otros cuatro países, según podemos leer en el informe del presidente Álvaro Obregón ante el Congreso (Informe, 2006), considerando esta fecha la del establecimiento de las relaciones formales (Relaciones, 1989:11). En otra publicación se consigna que tales relaciones formales se establecieron en los primeros meses de 1928, tras haber renovado México su propuesta de entablar las "formales relaciones diplomáticas" (Recomendaciones, 2015:13; Smolana, 2018: 46). Independientemente de la fecha, pronto resulta que las primeras décadas de las relaciones oficiales están marcadas por precauciones, pero también por prejuicios por parte de los diplomáticos de ambos países.

$\mathrm{Al}$ analizar los documentos de la época podemos reconstruir esta imagen resultante de diferentes experiencias políticas, sociales y culturales acerca de Polonia y polacos como nación, así como podemos observar un conjunto de valores y experiencias contrapuestas, expresadas y conceptualizadas por la parte polaca sobre México, reforzadas en la prensa nacional. El objetivo de la investigación es sistematizar la información trasmitida y difundida a través de las fuentes diplomáticas, y analizar el contenido valorativo del discurso oficial tras el establecimiento de las relaciones bilaterales mexicano-polacas.

\section{2.- FUNDAMENTACIÓN TEÓRICA}

Mitos: México bandolero y salvaje, Polonia en el medio de la nada

Fijémonos en primer lugar en los antecedentes. Junto a las circunstancias geopolíticas, fue la cultura popular - y más precisamente el heteroestereotipo de México, común en toda Europa a principio del siglo XX - el que proporcionó el fundamento para la imagen colectiva del país azteca. En cambio, para el México revolucionario Polonia era una nación desconocida. Además, llevaba más de cien años borrada como estado del mapa político de Europa y su territorio se encontraba repartido entre tres imperios: Prusia, Imperio Austrohúngaro y la Rusia zarista.

Ya Tadeusz Łepkowski el historiador polaco que analiza las relaciones polaco-mexicanas, subraya que la actitud de Polonia hacia México, que renació en 1918, estuvo en gran medida condicionada por el estereotipo imperante en la época. México era visto en Polonia como un país de una civilización antigua y misteriosa, cristianizada por los conquistadores españoles, pero también poco ilustrada y políticamente inestable. Era más un "Estado bandolero" que un exótico y pacífico oasis que disfruta de una economía desarrollada y dispone de una población trabajadora (Łepkowski, 1980:43). Se 
veía como socialmente dividido en el México criollo de los políticos y militantes, y el México indígena pobre y salvaje. Esta debilidad socioeconómica llevó a Estados Unidos a convertir el país vecino en un territorio de su rápida expansión. En el Viejo Continente, mantenía su vigencia la decimonónica tesis de Michel Chevalier, expuesta en Le Mexique ancien et moderne, que con la excepción de la plata que poseía, México era inútil para Europa (1863:67).

La distancia, el mutuo desconocimiento y un cierto desinterés aportaron pues a que la percepción del otro país se encaminase por los estereotipos. El fin de la Primera Guerra Mundial en Europa posibilitó la reaparición de Polonia. En el mismo año, 1918, en México terminó la Revolución, lo que trajo un nuevo orden político en este país. El periodo posterior a la Primera Guerra Mundial, tanto en Polonia, como en México, garantizó de alguna manera la posibilidad de normalización de la situación política en ambos países. A pesar de las mutuas miradas, en buena parte prejuiciadas, los dos países tenían algo en común: uno, recién recuperada su independencia y el otro recién salida de una revolución, enfrentaban el reto de reconstruir el país.

No obstante, con el paso de los años, se pusieron de manifiesto los valores e intereses contrapuestos defendidos por cada país. Prueba de eso es en la participación de ambos Estados en la Sociedad de Naciones: en el caso de la invasión italiana a Abisinia, en 1935, México la condenó y se negó a reconocer la anexión de este país africano a Italia. Polonia, en cambio, mantenía buenas relaciones con el gobierno de Mussolini. Del otro lado, en el caso de la guerra civil española, mientras México prestó auxilio a los republicanos derrotados y exiliados, Polonia, por el contrario, reprimía a sus ciudadanos que lucharon a favor de la República y en algunos casos hasta llegó a privarlos de la nacionalidad polaca (Łepkowski, 1986).

También influye en el distanciamiento político el hecho de escaso flujo migratorio del territorio polaco a México. Aunque hubo personas que inmigraron de Polonia a México, en el periodo de entreguerras se tuvo un censo de apenas 7500 personas (Jacórzyński y Kozłowski, 2015: 24). Conviene aclarar que muchos de estos migrantes pretendían llegar a Estados Unidos y que - aunque había declaraciones de coordinación de la política migratoria a nivel de gobiernos (Dębicz y Smolana, 1993: 17-40) - estas no se concretaron: ni antes ni después de la introducción del sistema de cuotas estadounidense. 
De hecho, no hubo ningún significativo vínculo previo, ni una experiencia social o cultural compartida, para que se puedan abstraer de ellas los valores o rasgos del otro, que estuvieran de alguna manera más fundamentados en la realidad.

\section{Tópicos: Polonia demasiado contrarrevolucionaria, México demasiado revolucionario}

Ya se ha dicho que las características que conlleva el concepto de Polonia y el concepto de México, difundidas en las primeras décadas del siglo $\mathrm{XX}$, derivan de una serie de prejuicios resultantes de un profundo desconocimiento mutuo. Además, en Polonia se popularizó bastante la opinión estadounidense acerca la situación política en México, según la cual el país generaba caos, desorden, crueldad, anticlericalismo y xenofobia (Łepkowski, 1980: 55-57).

En cambio, en México no se dieron antecedentes, ya que se desconocía Polonia simplemente. Podemos suponer que la inicial curiosidad y buenos sentimientos de los mexicanos hacia Polonia tenían que ver con el hecho de que la veían como un estado débil que, al igual que México, había sido víctima de vecinos poderosos.

Sin embargo, mientras que la Polonia renacida en 1918, veía a Rusia bolchevique con desconfianza y resentimiento, el México emanado de la revolución saludaba con entusiasmo a la Unión Soviética. La nueva situación geopolítica mundial influye en la consolidación de la valoración desfavorable en las relaciones bilaterales.

En el año 1922, Rodolfo Nervo, encargado de negocios a. i. de México en Francia, en su largo informe sobre su misión especial a Polonia anotó el interés de Polonia en las relaciones comerciales y sobre la posibilidad de migración de los ciudadanos polacos para establecerse en México como agricultores (Łepkowski, 1980: 60). Comenta también Nervo que "en lo tocante al reconocimiento de jure del gobierno mexicano por el de Polonia”, el gobierno polaco se regía por la política estadounidense, entonces, aunque las expresiones de interés y anhelos de formalizar las relaciones fueran reiteradas, da la impresión de que estas intenciones no eran de todo auténticas, sobre todo en cuanto a la parte polaca (AREM 30-29-35, 1922).

Otro obstáculo serio para el establecimiento de relaciones oficiales fue la cuestión religiosa. El gobierno polaco condenaba la guerra cristera en México, y entre la población se difundieron los reportajes 
y noticias de prensa sobre la represión de los católicos mexicanos, entre los cuales destaca el libro del escritor y viajero Melchior Wankowicz (1927). Con esta circunstancia está también relacionada, por ejemplo, la sugerencia del representante de Polonia en Estados Unidos, en 1926, a que su canciller retrasara la designación de un representante en México hasta que finalizara el conflicto (AAN 1929).

En 1928 México propuso nuevamente a Polonia establecer “formales relaciones diplomáticas”, a través del representante mexicano, acreditado y en funciones, en la República Checoslovaca, Leopoldo Blásquez Como resultado de esa gestión, el gobierno polaco, no sin referirse nuevamente a sus restricciones presupuestarias, nombró cónsul general en México a Zygmunt Merdinger. México, por su parte, nombró cónsul general a Raúl Rodríguez Duarte y abrió el consulado en Varsovia en 1929 (AREM 30-29-35).

En suma, las relaciones bilaterales en sus comienzos estaban condicionadas por las circunstancias y el contexto político de uno y otro país. Concluyeron en formalización definitiva de las relaciones diplomáticas, aunque no se evitaron roces. Zygmunt Merdinger tenía el rango de encargado de negocios y, en vista de ello, Polonia en 1930 nombró a Tytus Filipowicz, diplomático de carrera, como Enviado Extraordinario y Ministro Plenipotenciario. Entonces este mismo año México designó, con el mismo rango, a Rodolfo Arturo Nervo. Sin embargo, Tytus Filipowicz era sobre todo el embajador de Polonia ante el gobierno de Estados Unidos y residía en Washington. Esa condición y el hecho de terminar su misión en pocos meses incomodaron al gobierno mexicano. Los polacos terminaron nombrando a Merdinger, con un rango menor, el de encargado de negocios, como jefe de la legación, en vista de lo cual México retiró a su ministro plenipotenciario Nervo y dejando a Antonio Castro Leal como encargado de negocios a. i. Este nivel de las relaciones se mantuvo hasta el estallido de la Segunda Guerra Mundial en 1939.

\section{Observaciones: Polonia y México de cerca}

Las observaciones diplomáticas constituyeron una especie de nueva fuente modeladora y modificadora del concepto de uno y otro Estado y nación. La mala opinión y desinterés del lado polaco respecto a México estaban correspondidos por la opinión de los diplomáticos mexicanos acerca de Polonia y su desorganización financiera, laboral, educativa, problemas con las minorías y con el aseguramiento de sus fronteras. Aunque tratamos de mantener un amplio panorama temporal, analizando los documentos de 
varias décadas, son particularmente destacables los informes de Rodolfo Nervo (enviadas en el período entre 1921 y 1932) y de Luciano Joublanc Rivas (del período de 1933 a 1939).

En la primera etapa de las relaciones bilaterales encontramos varios oficios e informes de los diplomáticos mexicanos a sus superiores y a la inversa, en los cuales para apelar a Polonia se repite el término de "nación amiga", sobre todo en las cartas de Nervo (AREM: AEMF 110.2). El mismo representante no se abstiene de trasmitir a sus superiores las informaciones sobre los atributos negativos, en el contexto de las relaciones formales. Apunta a la desorganización protocolar e ignorancia, aunque lo considera "inevitable en un país que acaba de iniciarse en la vida internacional" (AREM: AEMF 79.15).

No obstante, las relaciones mexicano-polacas resultan poco fluidas y sin logros significativos para ambos países. La actitud polaca hacia México seguía, en general, poco amistosa. México se quejaba, por ejemplo, ya en los años 30, de la mencionada falta de reciprocidad en cuanto a las representaciones oficiales o de violaciones de la correspondencia diplomática por parte de Polonia (AREM: 438.1-0/510/1 Doc. ${ }^{\circ}$ 566, Varsovia, 15-10-35). Pero lo que causaba más rechazo y reforzó sin duda la imagen negativa de Polonia por fue la larga militarización del país. Joublanc Rivas escribe sobre "una oligarquía militar que encabeza el Mariscal José Pilsudski, héroe de la Independencia y amo de los destinos de la Republica” (AREM: III-1321-5 1. parte, f. s/n). En su descripción, Piłsudski, héroe de la independencia, jefe de Estado y de gobierno y finalmente dictador,

gobierna el país entre bastidores, pero con mano de hierro. Es una figura pintoresca, un hombre decidido a todo, que no titubeó ante el crimen y el latrocinio cuando se jugaban los destinos de su patria (ibidem).

El ministro concluye que este régimen despótico "repugna al amor natural del todo mexicano por las libertades cívicas y las fórmulas democráticas que con tanto sacrificio y a costa de tantas vidas apenas vamos comenzando a implantar en nuestro país" (ibidem). Asimismo, advierte, en relación con el tema de militarismo, que:

Polonia está tan alejada de nosotros que esta desdichada situación no puede afectarnos, y lo único que debemos hacer, si deseamos mantener relaciones cordiales con su gobierno, será abstenernos de cualquier crítica que pudiera herir su susceptibilidad (AREM: III 1321-5 2. parte, f. s/n). 
Polonia, según el cable del servicio exterior mexicano, se encontraba "ansiosa de figurar como gran Potencia europea y menospreciada a cada paso por las verdaderas grandes Potencias" (AREM: III1321-5 1. parte, f. s/n). Joublanc Rivas observa que Polonia ha reaccionado con un "nacionalismo agudo que ciega a sus habitantes hasta hacerlos caer en extremos que dejan de ser respetables, por patrióticos, para caer en la comicidad y el ridículo" (ibidem).

Cabe añadir que en su autoestereotipo Polonia, a pesar de la realidad política europea, se veía a sí mismo como "potencia media”, con peso suficiente para intervenir en la Europa de la preguerra y que aspiraba a ciertos territorios coloniales, por ejemplo, en África (AREM: Doc. n 175, Varsovia, 7-03-35. Joublanc. III/ 510 (438-0) 1135-4.).

Curiosamente, la defensa del jefe de estado Józef Piłsudski se puede encontrar también en los archivos mexicanos: en una nota del diplomático polaco Zygmunt Merdinger, de 1929, que contiene la protesta por un artículo aparecido en el periódico El Universal, en el que se difamaba al venerado mariscal.

\section{Realidades: factores económicos y culturales}

Una de las tareas más importantes de ambas misiones diplomáticas fue la promoción de la cooperación económica. En el año 1927 a México llegó la delegación del comité organizador de la Cámara de Comercio Polaco-Latinoamericana. Zygmunt Merdinger se daba cuenta de lo difícil que era organizar la cooperación, constatando: “el mercado mexicano es para nosotros completamente virgen y los esfuerzos de entrar en él realizados por la parte polaca, son mínimos” (AAN MSZ sygn. 11641). En el mismo documento, el plan de la promoción económica del Consulado General de Polonia proponía "informar prácticamente a las esferas mexicanas de comercio sobre el tipo de productos y la mercancía de fabricación polaca" (ibidem).

En distintas ocasiones los representantes de los dos países trataron de llegar a un tratado comercial: por ejemplo, en 1930 el embajador Rodolfo Nervo sugirió un arreglo aduanal. El mismo diplomático informaba también del descubrimiento polaco de unos neumáticos "impicables" y de la pretensión de Polonia, de que México invirtiera en su fabricación (AREM, informe del 1932-03-31). Ante la negativa mexicana, por falta de recursos, el $1^{\circ}$ de mayo de 1931 el gobierno polaco prohibió la importación de productos mexicanos a Polonia. 
Los dos sucesores de Nervo intentaron también la concertación del tratado. Castro Leal terminó informando que ni México ni Polonia estaban en condiciones de acordarlo, porque Polonia recién arribada a su independencia, carecía de comunicaciones con América y que ninguno de los dos países tenía fondos para créditos a la exportación. (933-04-04; 1933-06-07; 1933-08-28; 1933-10-11; 1936-02; 1938-03-10; 1939-05-30).

En efecto el intercambio comercial presentaba un desarrollo lento y poco satisfactorio para ambos países.

Cuadro 1.

El valor del intercambio comercial entre México y Polonia en los años 1935-1939

\begin{tabular}{rcccc}
\hline Año & $\begin{array}{l}\text { Exportación de Polonia } \\
\text { México, valor en pesos }\end{array}$ & $\begin{array}{l}\text { Exportación de } \\
\text { Polonia, valor en pesos }\end{array}$ & $\begin{array}{c}\text { México alance } \\
\text { polonia }\end{array}$ \\
\hline 1935 & 601.023 & 69.987 & +531.136 \\
1936 & 678.451 & 1.263 .377 & -594.926 \\
1937 & 1.800 .749 & 984.702 & +816.047 \\
1938 & 1.993 .852 & 923.573 & +1.070 .279 \\
1939 & 984.496 & 710.623 & +273.873 \\
\hline
\end{tabular}

Fuente: Smolana (2018, p. 67).

Dados los débiles resultados del intercambio comercial en el primer período del funcionamiento de la representación diplomática, en el año 1930 iniciaron las conversaciones sobre la firma de un tratado comercial. A principio del año 1936 se celebró un encuentro bilateral con el fin de negociarlo. Sin dar resultados en concreto, la parte mexicana suspendió las negociaciones en julio de 1936.

La falta de efecto de las conversaciones oficiales no imposibilitó la actividad de particulares y sus empresas. Los inmigrantes polacos, sobre todo los judíos polacos, organizaron la importación, por lo general no muy numerosa, de productos polacos a México. Entre el año 1934 y 1935 se formó la Compañía Mercantil Transmarítima S.A. Sus fundadores, Herman Rubin, Marek Maus, Zygmunt Reisbaum y Henryk Schrenzel, desarrollaron el negocio de importación-exportación entre Polonia y México. De Polonia importaban lúpulo, malta para la fabricación de cerveza, jamones etc. (Łepkowski, 1986). En 1939 vino a México el coronel emérito Jan Skoryna, como enviado del Consejo de Comercio 
Exterior Polaco, para organizar la exportación de los productos polacos, sobre todo los productos de la industria pesada. Iba también a investigar las posibilidades de la importación de materia prima de México a Polonia. Parece que su misión habría sido exitosa, si no fuera por el estallido de la Segunda Guerra Mundial.

El comercio, así como la cultura, pudieran haber elevado la calidad de la relación diplomática, y, en consecuencia, mejorar la percepción colectiva de ambos países. Sin embargo, aunque el mismo Merdinger admitiera en 1933 que "el intercambio entre Polonia y México reviste un carácter cada vez más amplio" (AREM III-137-13, f, s/n), los asuntos comerciales no dieron mayores resultados. Es más, los informes mexicanos transmiten una imagen de Polonia cada vez más desfavorable. Si bien el memorándum mexicano del mismo año (AREM III 2318-1, f. s/n.) expresa el deseo de "grandes proporciones del comercio en época no muy lejana", dado que "ambos países están en pleno desarrollo", en el mismo documento hace la observación general de "encontrarnos en una época tan desfavorable como la presente" (ibidem), que es una alusión a los incesantes inconvenientes que no permiten celebrar el tratado de comercio con Polonia.

Los expedientes reportan pequeños avances en asuntos del intercambio cultural, pero también relatan roces por la exhibición de películas y la difusión de publicaciones denigrables, como el filme polaco La Paloma o la producción mexicana La sangre polonesa (Relaciones, 1989: 12-15). Al mismo tiempo Joublanc Rivas expresa en el informe su estima por la literatura polaca:

Las joyas literarias de Polonia, cuyos escritores descuellan especialmente en el campo teatral, están destinadas pues a ser conocidas en México únicamente por una pequeña élite, que podrá leerlas en traducciones francesas. El resto del público tendrá que conformarse con Sienkiewicz y Ossendowski (AREM: III-1321-5, 3. parte f. s/n).

En los cables se encuentran críticas entusiasmadas de los músicos y compositores considerándolos el factor esencial de lo polaco, además libre del idioma, "uno de los más difíciles que hay actualmente en el mundo" según Joublanc Rivas. Describe además a los polacos como la "nación artística por excelencia" (ibidem.)

Paralelamente al contacto oficial, en Polonia se extiende el concepto de México bárbaro, comunista y anticatólico. El reconocido escritor polaco Melchior Wańkowicz en 1927 publica en Varsovia un libro de reportajes titulado W kościołach Meksyku [En las iglesias de México], fruto de su 
viaje y estancia de algunos meses en México. Logra acercar la temática mexicana al público polaco, pero al mismo tiempo refuerza la imagen del país bandido y cruelmente anticatólico, enfocando la atención de los lectores en la destrucción de la fe cristiana.

En 1933, causando roces y violentas polémicas, aparecieron en la revista Polacy w Catym Świecie [Polacos en el Mundo Entero] varios artículos difamatorios, entre ellos el titulado: "Meksyk, żeby cię pochłonęło piekło na ziemi [México, que desaparezcas infierno sobre la tierra]”, con una felicitación a la revista, firmada por Tadeusz Jarocki, agregado de la legación de Polonia en México (Stankiewicz, 1933).

Figura 1.

3 imágenes del artículo difamatorio en la revista Polacy w Calym Swiecie, 1933:11-12.

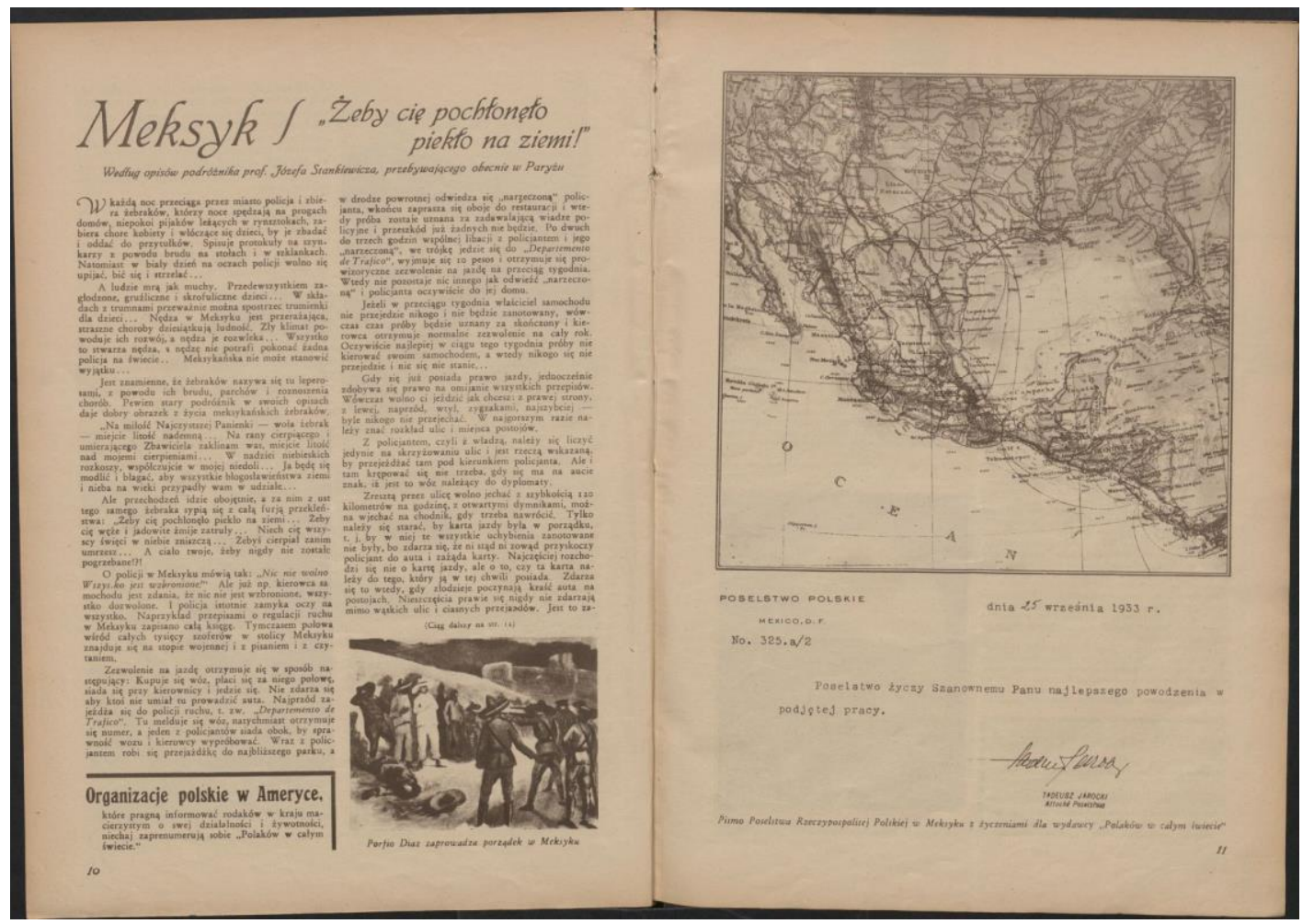



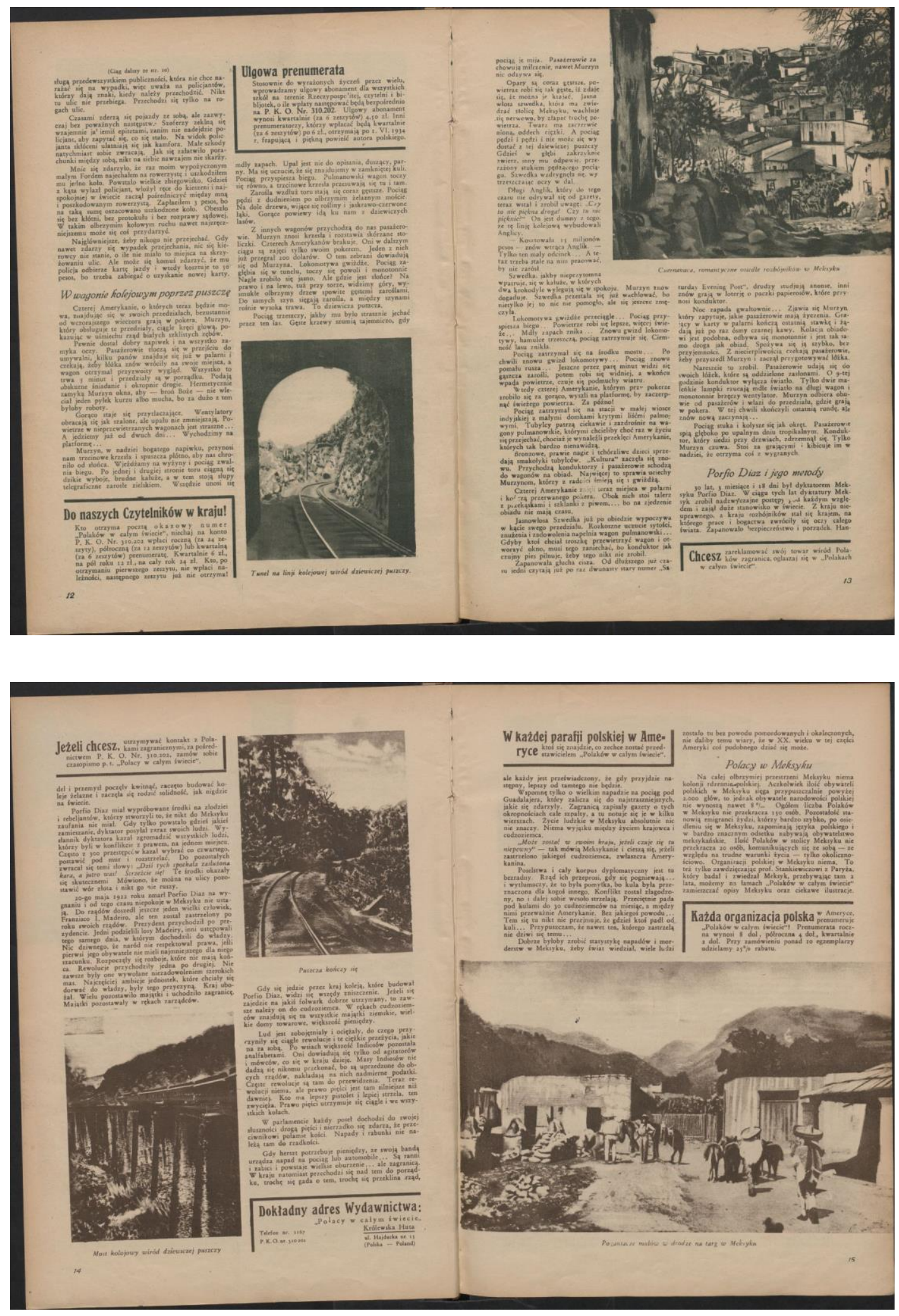

Fuente: Stankiewicz (1933). 
En la misma década, repetidamente en el periodo de 1932 a 1939, no se autorizó en Polonia el uso de la radio, solicitado por la misión diplomática mexicana, para hablar del aniversario de la independencia de México (Relaciones, 1989: 25-31). En 1935 Joublanc Rivas comentará disgustado, en un cable a su cancillería, que en Polonia "se sigue el sistema de obtener el máximo de concesiones y ventajas con un mínimo de reciprocidad o nada, si es posible.” (ibidem).

La discrepancia religiosa, que dio lugar a la Guerra Cristera en México, era otro factor que tanto el gobierno polaco como la población, en gran parte católica, condenaban. Para los diplomáticos era difícil "encontrar un punto de contacto que haga posible el acercamiento y la simpatía" hacia la Polonia espiritual que notaban, en efecto, susceptible, acomplejada y fanática. Joublanc Rivas observa: "con excepción del idioma, estimo que las tendencias políticas y el fanatismo religioso (católico), tan característico de este país, son los mayores obstáculos para su acercamiento con el nuestro" (AREM: III1321-5 1. parte, f. s/n).

El encargado de negocios a.i. aconseja en el mismo informe, que si hay interés en un acercamiento con Polonia:

La mejor manera de conquistar la amistad y buena voluntad del pueblo y el gobierno polaco sería el demostrar, por todos los medios posibles, un sincero interés en su existencia como país independiente, en primer lugar; y después, tener siempre muy presente a Polonia en cualquier acto de carácter internacional al que sean invitadas las grandes Potencias; exteriorizar la admiración por sus grandes hombres (...); y evitar cuidadosamente cualquier pequeña omisión o crítica a la que una gran Potencia no concedería importancia, pero que Polonia, por sus circunstancias especiales, consideraría como deliberada ofensa, pues difícilmente habrá en estos momentos otro país en el mundo que tenga una susceptibilidad tan desarrollada (AREM: III 1321-5).

De hecho, en los próximos años, el tema "Polonia" se convertiría en el "problema polaco" (AREM: III726-7, f. s/n). Polonia, a lo largo del periodo de entreguerras, perdió su imagen positiva y en los años cuarenta, pasando a concebirse como un país, un socio con una particular "nota exótica" (AREM: III-2413-16, f. s/n).

Sin embargo, en Polonia, en la misma década, que atrapó a este país centroeuropeo en la situación de otra guerra mundial, el concepto polaco de México cambia radicalmente, dando paso a una imagen de 
"la tierra prometida" y "bendita tierra de paz" (AREM: III 639-10, f. s/n y AREM: III 2413-16, f. s/n.). Esta imagen se debe en gran parte a la maniobra política multinacional de establecimiento de la colonia Santa Rosa, Guanajuato: asunto ya estudiado y documentado en varias investigaciones, como la de Smolana (2018) o Carreño y Zak (2001).

\section{3.- MÉTODO}

Con el fin de reunir los datos necesarios para describir y caracterizar los inicios de las centenarias relaciones diplomáticas mexicano-polacas, empleamos un análisis documental, basándonos en la revisión del material escrito reunido en los archivos nacionales de ambos países.

Los documentos fueron consultados tanto en forma de antologías de fuentes, como por medio de acceso directo al acervo histórico que conserva los documentos originales. Se trata principalmente del conjunto publicado por el Archivo Histórico Diplomático Mexicano: Relaciones México Polonia 1921/1989. Cronología y documentos (1989). Los expedientes consultados se encuentran archivados en el Archivo Histórico Genaro Estrada en México (Archivo de Secretaría de Relaciones Exteriores AREM). En caso de las fuentes polacas, contamos con la extensa colección de Archiwum Akt Nowych - AAN y el Archiwum Ministerstwa Spraw Zagranicznych.

La selección de fuentes generadas por ambas naciones resultó útil para diseñar tanto el tamaño como el rango de la investigación. Esta estrategia también permitió la comparación y organización del material para obtener las citas textuales relativas a diferentes plataformas de contacto y cooperación bilateral.

Las fuentes que posibilitaron este análisis incluyen entonces los documentos institucionales. Se trata sobre todo de los textos oficiales expedidos por el servicio exterior mexicano, emitidos entre el año 1921 y 1945. Es el marco temporal comprendido entre el mencionado informe presidencial de Álvaro Obregón sobre el reconocimiento de Polonia (1921) y el cable cifrado del embajador de México en Londres, Rosenzweig Diaz sobre la actitud del gobierno mexicano respecto el desconocimiento del gobierno de Polonia en exilio del año 1945. Son varios formatos diplomáticos: informes, oficios, cartas, memorándum, telegramas, boletines generados por el servicio exterior mexicano o polaco. 
Para complementar este análisis cualitativo nos nutrimos de los escasos textos periodísticos y literarios de la época: las narraciones de viajeros o escritores, sobre todo de Melchior Wankowicz, cuya visión no difiere mucho de lo que se puede leer en los cables.

El cuerpo de este trabajo por su naturaleza no es un conjunto completo, dado que a menudo no era posible acceder a ciertas partes de los acervos, no todas las fuentes se consiguen en original, además muchos expedientes siguen clasificados o discontinuos. La lectura crítica de este material textual y su ubicación en el contexto sociopolítico de la época, nos parecieron proporcionar el mejor instrumento para elaborar una interpretación del asunto investigado.

La investigación fue realizada en varias etapas. La selección del tema coincidió con el centenario de la independencia de Polonia y la celebración del 90 aniversario del establecimiento oficial de las relaciones diplomáticas mexicano-polacas.

\section{4.- CONCLUSIONES}

Los estudios e informes sobre las relaciones bilaterales entre México y Polonia, aunque no numerosos, reflejan el interés y relevancia del intercambio entre ambos países. En las últimas décadas se observa la intensificación de mecanismos de cooperación y áreas de relaciones, sobre todo en la economía (Recomendaciones, 2016:10-11).

No obstante, los intercambios son limitados y no reflejan el potencial que tienen ambos países. En 1928 comenzó un diálogo político que ha carecido de regularidad o dinámica. A lo largo de los decenios, los contactos de alto nivel eran esporádicos (Smolana, 2017:132-135) y también se observaba la escasez de otros mecanismos de cooperación en el ámbito comercial, científico o multilateral. Siguiendo las conclusiones de las Recomendaciones para el fortalecimiento de las relaciones México y Polonia (2016) podemos concluir que las estrategias de acercamiento hacia el otro país recién tomaron impulso en el siglo XXI.

En el contexto de nuestra investigación vemos que las particularidades de los casi centenarios contactos políticos y económicos de Polonia y México no han contribuido en el conocimiento mutuo y la falta de fomento de información o intercambio más intenso de alguna manera ha petrificado la inicial relación de "distancias y mitos". En el presente estudio pretendemos testimoniar el punto de partida y la 
etapa inicial de la promoción de los respectivos países en el ámbito de las relaciones bilaterales. Al documentar el carácter y la dinámica del inicio de contactos diplomáticos a través de la mirada crítica del cuerpo diplomático y mundo mediático, nos enfocamos en las actitudes y conceptos que hoy en día llamaríamos estrategias de promoción o de imagen. Como vimos en las opiniones citadas, hace un siglo, cuando los dos países, Polonia y México, empezaban a acomodarse en el teatro político internacional, las relaciones caían en la trampa de los mutuos estereotipos.

La falta de algún vínculo significativo o cualquier experiencia compartida aportó a que en Polonia prevaleciera la imagen del México bandolero y salvaje, reforzada además en las primeras décadas del siglo pasado por la cinematografía estadounidense. Las imágenes de México como un país en desorganización total encontraron también espacio en la prensa y literatura polacas.

En la política exterior de ambos países, el entusiasmo por el reconocimiento mutuo resultó de corta duración. Pronto los diferentes conceptos políticos dificultaron la cooperación. En el ámbito internacional, México promovía la doctrina Estrada de no intervención en asuntos internos y la defensa de cualquier país que sufriera agresiones externas. Polonia, en cambio, mostraba su ansia de "figurar como gran Potencia europea" intentando participar activamente en la geopolítica de entreguerras. A pesar de que los iniciales informes de los diplomáticos mexicanos daban cuenta del paralelismo de la vida política de ambos países, con el tiempo se volvió evidente que la recién resucitada Polonia priorizaba sus asuntos internos y las relaciones exteriores no se iban a intensificar. Es más, se consolidaron los tópicos, tanto en el campo de la política y economía como de la espiritualidad y cultura.

Los documentos estudiados ponen en evidencia que, aunque los gobiernos mexicanos buscaron contrarrestar la imagen popular desfavorable de su país, paso a paso se daban cada vez más casos del desentendimiento. El tópico de "México: demasiado revolucionario" parece arraigarse en la opinión publica polaca, formándose principalmente sobre la base del discurso político estadounidense, pero también en consecuencia de la percepción de las medidas tomadas contra la Iglesia católica durante la denominada Guerra Cristera. Para Polonia, un Estado multiétnico que a fuerza procuraba formar una nación monolingüe y católica, las restricciones constitucionales mexicanas, como por ejemplo la prohibición de la participación política de la Iglesia, la censura al culto público fuera de los templos o la restricción de poseer bienes raíces, se asemejaban a la barbarie comunista del potente vecino soviético. No faltaron pues motivos para reforzar la imagen negativa, sobre todo en las revistas católicas o sociales y en la narrativa, sobre todo de Melchior Wańkowicz. 
En cambio, la imagen de "Polonia: demasiado católica" aparecía con más frecuencia en los informes de la legación mexicana en Varsovia y se interpretaba el papel de la religión no solamente como una característica que el Estado polaco aprovechaba para contrastar el bolchevismo soviético, sino se lo veía claramente como una herramienta de gestión interna y una expresión del conservadurismo social. Los expedientes estudiados hacen referencia a los asuntos internos de la gestión de minorías étnicas y religiosas y observan la institucionalización del catolicismo polaco.

En el presente análisis no se ha incluido el tema de los judíos polacos y el papel que pudo tener el asunto de la migración judía en cuanto a la consolidación de la imagen mutua. Es un tema muy amplio y el aporte de la percepción de los judíos ciudadanos polacos a la formación del imaginario de México y de Polonia en el extranjero merece un estudio detallado aparte.

Los expedientes documentan que los primeros veinte años de relaciones oficiales entre México y Polonia no proporcionaron provechos económicos ni comerciales. Surgieron varias iniciativas, pero por lo visto faltaron tanto los fondos como un verdadero interés económico. Además, según las fuentes estudiadas, la ausencia de un marco legal para la cooperación (la firma de un tratado bilateral no se logró) desanimaba a los posibles socios, mientras que las recurrentes rupturas de las negociaciones previas causaron un distanciamiento y desconfianza de negocios.

En cuanto a las relaciones culturales, pudimos documentar tanto avances como disonancias. La estereotipización del imaginario (social y político) de México y de Polonia en el extranjero dificultaba la difusión cultural mutua. A pesar de los esfuerzos de los diplomáticos, el reconocimiento cultural sufría también la influencia de los tópicos, preservados por los medios. En los expedientes oficiales, no obstante, encontramos informes e opiniones que documentan un gran aprecio a la cultura del país amigo, sobre todo en cuanto a las actividades artísticas en el campo de la música. Sin embargo, desde el punto de vista de la intensidad de cooperación, de ninguna manera se puede hablar de un significativo intercambio cultural o científico. Más bien, las relaciones culturales, a semejanza con las políticas, sociales o económicas, estuvieron cargadas de los tópicos iniciales difícilmente superables.

Basándonos en los materiales estudiados observamos, a pesar de la carga del estereotipo, que en las primeras décadas de las relaciones bilaterales se dio una paulatina evolución cualitativa del concepto de Polonia y de México. En caso de este primer país, su imagen indiferente se volvió desfavorable. En cambio, la imagen de México evolucionó de plenamente negativa a moderadamente favorable. 
Actualmente, las consecuencias de estas imágenes incómodas ya parecen vencidas en las relaciones bilaterales, tanto las políticas como las económicas. Sin embargo, los tópicos han dejado rastro en la cultura popular y en el lenguaje o formas de comunicación. El impacto que estos estereotipos todavía pueden tener en diferentes áreas de cooperación y contactos bilaterales es un interrogante que valdría la pena plantearse en futuro. En este contexto parecería recomendable un detallado análisis de la documentación contemporánea, con el objetivo de aportar para el diseño de unas eficaces políticas de promoción de imagen.

\section{REFERENCIAS}

Archivo Histórico Genaro Estrada (Archivo de Secretaría de Relaciones Exteriores - AREM).

Archiwum Akt Nowych (AAN).

Cámara de Diputados. (2006). Informe presidencial de Álvaro Obregón $1^{\circ}$ de septiembre de 1921. Cámara de Diputados Dirección General de Investigación y Análisis.

Carreño Alvarado G. y Zak de Zukerman C. (2001). El convenio ilusorio: refugiados polacos de guerra en México (1943-1947). Cartapacio.

Chevalier, M. (1863). Starożytny i nowożytny Meksyk. Biblioteka Warszawska.

Jacórzyński, W. R. y Kozłowski, M. J. (2015). Rostros de la presencia polaca en México: un vuelo a través de la historia. Ulúa. Revista de Historia, Sociedad y Cultura, 26, 11-44.

Dęmbicz, A. y Smolana, K. (1993). La presencia polaca en América Latina. CESLA Uniwersytet Warszawski.

Łepkowski, T. (1980). Polska-Meksyk 1918-1939. Ossolineum.

Łepkowski, T. (1986). Historia Meksyku. Ossolineum.

Secretaría de Relaciones Exteriores México (1989). Relaciones México-Polonia, 1921-1989. Cronología y documentos. Archivo Histórico Diplomático Mexicano.

Secretaría de Relaciones Exteriores (2015). Recomendaciones para el fortalecimiento de las relaciones México y Polonia. Instituto Matías Romero.

Smolana, K. (2018). Polonia y México a lo largo de la historia: una perspectiva desde la misión diplomática polaca. Instituto Matías Romero.

Stankiewicz, J. (1933). Meksyk, żeby cię pochłonęło piekło na ziemi. Polacy w Całym Świecie: czasopismo ilustrowane poświęcone emigracji polskiej. Królewska Huta, 10-15. 
Kwiatkowska-Faryś, E.

Stankiewicz, J. (1933). Meksyk, kraina wiecznej rewolucji. Polacy w Całym Świecie: czasopismo ilustrowane poświęcone emigracji polskiej. Królewska Huta, 25-27.

Wańkowicz, M. (1927). W kościołach Meksyku. Towarzystwo Wydawnicze Rój. 